Quantum-chemical modeling of the photo-oxidation reaction of acetylene by nitrocompounds

Sergei D. Plechovich, Sergei V. Zelentsov, Yuri V. Minasyan

E-mail: senypl@mail.ru

Nizhnii Novgorod State University

Russia, 603950, Nizhnii Novgorod, Gagarin Ave., 23. NNGU. Chemical Department

Abstract: The simulation of photooxidation reaction of acetylene by triplet nitro compounds was performed by means of the uB3LYP/6-31g+(d) quantum chemistry method. $\mathrm{HNO}_{2}$ was selected as an oxidizing agent, and acetylene was used as a substrate in quantum chemistry calculations of the reactions giving glyoxal as a product. The final product is obtained in four stages, the transition state geometry and activation energy were determined for all steps involved.

Keywords: uB3LYP, reaction mechanism, the triplet state, transitional state, imaginary frequency

\title{
INTRODUCTION
}

The photochemical oxidation of olefins by nitrocompounds has previously been studied in [1]. The result of this reaction is ethylene oxide, when ethylene being selected as the oxidizable component. The reaction proceeds in two stages [1]. It is interesting to study the similar addition reaction taking acetylene as the oxidizing component. We have performed quantum chemical calculations of the transition states involved in the reaction and have tried to propose its mechanism.

\section{METHODOLOGICAL PART}

The quantum - chemical modeling of reaction of photooxidation of acetylene by nitro compounds has been performed by uB3LYP/6-31g+(d) method. A software package Gaussian-03 [2] has been used for the calculations. The choice of method of calculation is based on the results of [1].

The criterion of the correctness of the transition state geometry finding was a presence of the only "imaginary" frequency. Refining of the transition state 
geometry was performed by the IRC method. The activation energies of the reactions were calculated as a difference between total energies with zero-point energies addition of the initial molecular system and corresponding transitional state.

\section{RESULTS}

The proposed reaction mechanism between acetylene and nitro compound consists of four stages. There has place an addition of the triplet nitrocompound to a acetylene molecule in the first stage.

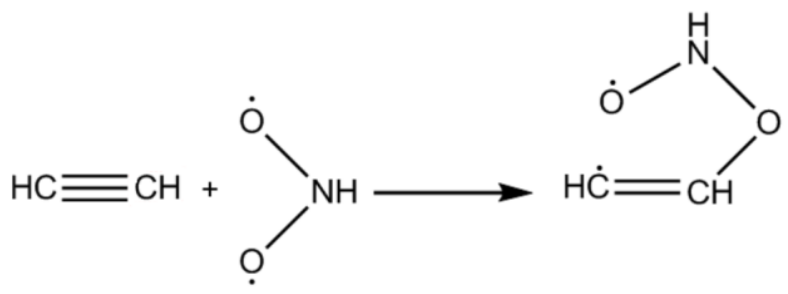

The spin density is concentrated on the oxygen atoms and with the value of 0.75 and 0.75 a nitro compound, thus it shows that it is in the triplet state, and the oxygen atom 0.49 and carbon 1.1178 in the reaction product. Spin density values are shown in Table 1 . The activation energy of the first stage was $5.63 \mathrm{kcal} \mathrm{mol}^{-1}$. The activation energy can be found in Table 2. The transition state is shown in Figure 1.

In the second stage, an addition of the second nitro compound molecule to the product of step 1 occurs in the triplet state.

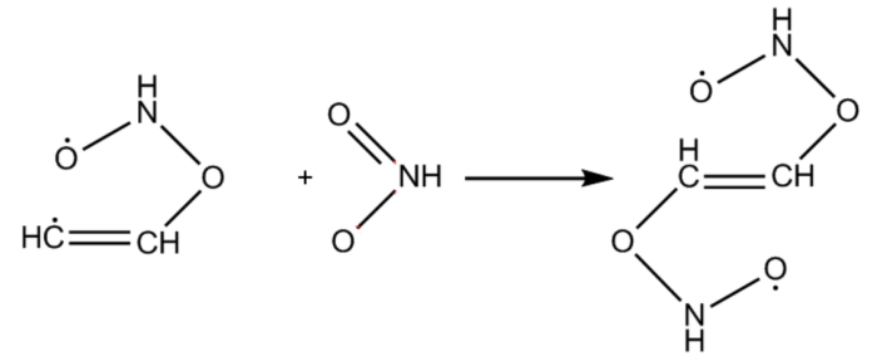

Addition of the nitro compound occurs in the triplet state with spin density being of 0.7515 and 0.7486 at oxygen atoms. The activation energy of this stage was $10.44 \mathrm{kcal} \mathrm{mol}^{-1}$. The transition state is shown in Figure 1.

At the third stage and fourth stage there occurs a decay of the second stage product to form at the end glyoxal at the singlet state and nitroso compound at the triplet state. 
<smiles>CC(C)CONONONO</smiles>

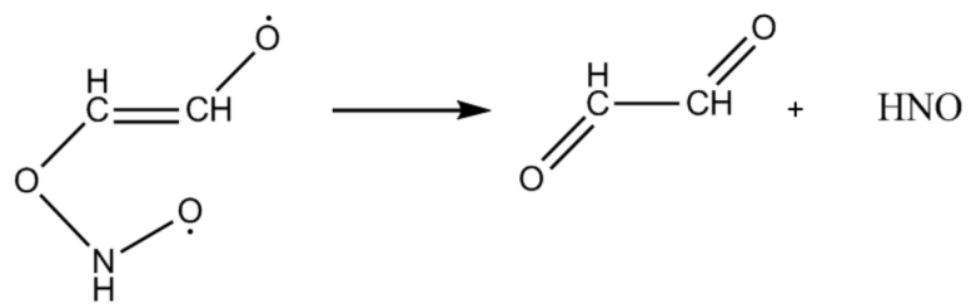

The values of spin density on the nitrogen and oxygen atoms are of 1.0600 and 0.8544 , respectively. The activation energies of reaction (3) and (4) are 12.12 and $6.21 \mathrm{kcal} \mathrm{mol}^{-1}$. The transition state is shown in Figure 1.

Table 1. Distribution of spin densities at the 4th step

\begin{tabular}{|c|c|c|c|c|}
\hline & $\mathrm{C}_{2} \mathrm{H}_{3} \mathrm{O}_{3} \mathrm{~N}$ & $\mathrm{C}_{2} \mathrm{H}_{2} \mathrm{O}_{2}$ & $\mathrm{HNO}$ & transition state \\
\hline$(1) \mathrm{C}$ & -0.04 & 0.00 & - & -0.08 \\
\hline$(2) \mathrm{C}$ & 0.63 & 0.00 & - & 0.48 \\
\hline$(3) \mathrm{N}$ & - & - & - & - \\
\hline$(4) \mathrm{O}$ & 0.33 & 0.00 & - & 0.21 \\
\hline$(5) \mathrm{O}$ & - & - & - & - \\
\hline$(6) \mathrm{O}$ & 0.15 & 0.00 & - & -0.11 \\
\hline$(7) \mathrm{O}$ & 0.54 & - & 0.85 & 0.74 \\
\hline$(8) \mathrm{N}$ & 0.00 & - & 1.06 & 0.69 \\
\hline
\end{tabular}




\begin{tabular}{|c|c|c|c|c|}
\hline & $\mathrm{C}_{2} \mathrm{H}_{2}$ & $\mathrm{HNO}_{2}$ & $\mathrm{C}_{2} \mathrm{H}_{3} \mathrm{O}_{2} \mathrm{~N}$ & transition state \\
\hline (1)C & 0.00 & - & 1.12 & 0.29 \\
\hline (2)C & 0.00 & - & -0.20 & 0.29 \\
\hline$(3) \mathrm{N}$ & - & 0.46 & 0.44 & 0.45 \\
\hline (4)O & - & 0.75 & 0.06 & 0.47 \\
\hline \multirow[t]{2}{*}{ (5) $\mathrm{O}$} & - & 0.75 & 0.49 & 0.47 \\
\hline & $\mathrm{C}_{2} \mathrm{H}_{3} \mathrm{O}_{2} \mathrm{~N}(\mathrm{~T})$ & $\mathrm{HNO}_{2}$ & $\mathrm{C}_{2} \mathrm{H}_{4} \mathrm{O}_{4} \mathrm{~N}_{2}$ & transition state \\
\hline (1)C & 1.12 & - & -0.00 & 0.30 \\
\hline (2)C & -0.19 & - & 0.04 & 0.38 \\
\hline$(3) \mathrm{N}$ & 0.44 & - & 0.43 & 0.14 \\
\hline (4) $\mathrm{O}$ & 0.06 & - & 0.06 & 0.13 \\
\hline$(5) \mathrm{O}$ & 0.49 & - & 0.07 & 0.04 \\
\hline (6) $\mathrm{O}$ & - & 0.46 & 0.50 & 0.07 \\
\hline (7)O & - & 0.75 & 0.47 & 0.50 \\
\hline \multirow[t]{2}{*}{$(8) \mathrm{N}$} & - & 0.75 & 0.42 & 0.48 \\
\hline & $\mathrm{C}_{2} \mathrm{H}_{4} \mathrm{O}_{4} \mathrm{~N}_{2}$ & $\mathrm{C}_{2} \mathrm{H}_{3} \mathrm{O}_{3} \mathrm{~N}$ & $\mathrm{HNO}$ & transition state \\
\hline$(1) \mathrm{C}$ & -0.00 & -0.04 & - & 0.05 \\
\hline (2)C & 0.04 & 0.63 & - & 0.06 \\
\hline$(3) \mathrm{N}$ & 0.43 & - & 0.00 & 0.38 \\
\hline (4)O & 0.06 & 0.33 & - & 0.07 \\
\hline$(5) \mathrm{O}$ & 0.07 & - & 0.00 & 0.45 \\
\hline$(6) \mathrm{O}$ & 0.50 & 0.15 & - & 0.04 \\
\hline (7)O & 0.47 & 0.54 & - & 0.44 \\
\hline$(8) \mathrm{N}$ & 0.42 & 0.00 & - & 0.46 \\
\hline
\end{tabular}









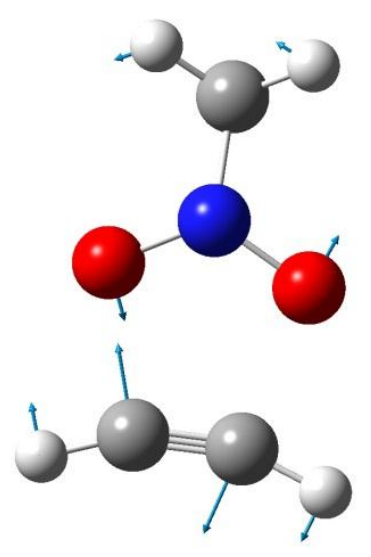

$375 i \mathrm{~cm}^{-1}$



$126 i \mathrm{~cm}^{-1}$
(1)

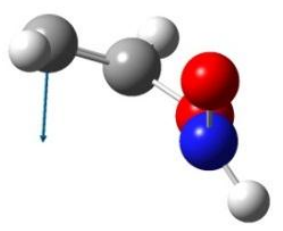

(2)

$$
1083 i \mathrm{~cm}^{-1}
$$

(3)

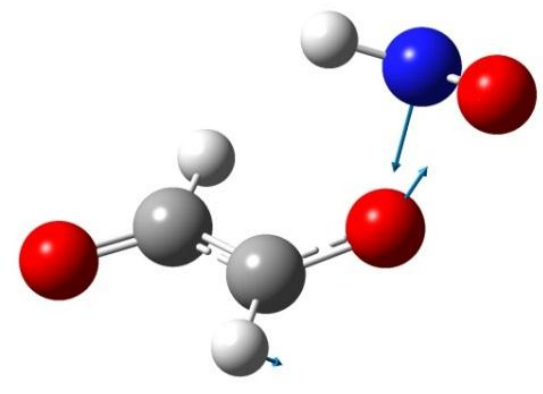

Fig.1 Transition states of the investigated reaction (1-4 - stage reaction)

\section{CONCLUSIONS}

The method uB3LYP/6-31 + g (d) revealed that photo-oxidation reaction of acetylene by nitrocompound includes four stages. At the first stage, a non-cyclic compound triplet, At the second stage the adduct adds another nitrocompound molecule. After destruction of the second stage product at the third and fourth stages a glyoxal molecule is formed. The activation energy of the rate-limiting step is of $12.12 \mathrm{kcal} \mathrm{mol}^{-1}$. 


\section{References}

1. Gaussian 03, Revision B.03, Frisch M.J., Trucks G.W., Schlegel H.B., Scuseria G.E., Robb M.A., Cheeseman J.R., Montgomery J.A., Jr. Vreven T., Kudin K.N., Burant J.C., Millam J.M., Iyengar S.S.,Tomasi J., Barone V., Mennucci B., Cossi M., Scalmani G., Rega N.,. Petersson G.A, Nakatsuji H. , Hada M., Ehara M., Toyota K., Fukuda R., Hasegawa J., Ishida M., Nakajima T., Honda Y., Kitao O., Nakai H., Klene M., Li X., Knox J.E., Hratchian H.P., Cross J.B., Adamo C.,Jaramillo J., Gompert R.S., Stratmann R.E., Yazyev O.,. Austin A.J, Cammi R., Pomelli C., Ochterski J.W., Ayala P.Y., Morokuma K., Voth G.A., Salvador P., Dannenberg J.J., ZakrzewskiV.G., Dapprich S., Daniels A. D., Strain M.C., Farkas O., Malick D.K., Rabuck A.D., Raghavachari K., Foresman J.B., Ortiz J.V., Cui Q., Baboul A.G.,Clifford S.,Cioslowski J., Stefanov B.B., Liu G., Liashenko A., Piskorz P., Komaromi I., Martin R.L., Fox D.J., Keith T., AlLaham M.A., Peng C.Y., Nanayakkara A., Challacombe M., Gill M.W., Johnson B., Chen W., Wong M.W., Gonzalez C., Pople J.A., Gaussian, Inc., Pittsburgh PA, 2003.

2. Plekhovich S.D., Zelentsov S.V., Plekhovich A.D. // Proceedings of Lobachevsky state university of Nizhni Novgorod. 2011. No. 6. P.121-126 